https://doi.org/10.18485/iipe_60nam.2021.ch26

\title{
INDONESIA AND THE NON-ALIGNED MOVEMENT: BEING CUSTODIAN OF A PRINCIPLED WORLD AND NAVIGATING THROUGH THE CHALLENGES OF FUTURE RELEVANCE AND SIGNIFICANCE
}

\author{
Yayan Ganda HAYAT MULYANA ${ }^{1}$
}

\begin{abstract}
The article explores Indonesia's role in the Non-Aligned Movement (NAM) and its leadership during its NAM chairmanship in 1992-1995. It further discusses the country's stewardship in transitioning the Movement into the new era of the post-Cold War, and in assuring its continued relevance within a new context of international relations. It also presents a brief survey of the NAM since its first Summit in Belgrade in 1961. This article presents a further discussion on the future significance of the Movement, looking at the present challenges that include Covid-19. It argues that the Movement will continue to be relevant for the $21^{\text {st }}$-century international relations. It will remain pertinent if the NAM is able to diversify leadership, show greater visibility in solving global problems, generate deliverables, enhance commitment depth, uphold the unity of voice and increase the level of multi-stakeholders internal support and participation.

Key words: Dasasila Bandung; New International Economic Order; leadership diversification, commitment depth, unity of voice.
\end{abstract}

\section{Introduction}

At 60 years old, the Non-Aligned Movement (NAM) becomes one of the oldest post-war international forums founded at the height of the Cold War. It not only survived the Cold War but also shaped its dynamics and

\footnotetext{
${ }^{1}$ Head of the Centre for Education and Training Ministry of Foreign Affairs, Jakarta, Indonesia.

E-mail: yayanghmulyana66@yahoo.com
} 
geopolitics. It offered an alternative avenue for countries to navigate their foreign policy in the midst of the bipolar world. The Movement played a critical role as a negotiating pole within the UN system, especially in the consideration of matters that posed threats to international peace and security.

As the Cold War ended in the early 1990s, the Movement had to respond to the question of whether it was still relevant. The urgency of the Movement to define its future direction as the global context was changing was coinciding with Indonesia's chairmanship of the NAM. In a summit in Jakarta in 1992, the NAM leaders affirmed the continued pertinence of the Movement in the changing milieu of international relations. They believed that the world was still far from being peaceful and just, and therefore it remained critical for the NAM to play a role and make a contribution.

While there had been unanimity among its members about the persistent relevance of the Movement, some quarters outside the Movement, however, had expressed doubts about the Movement's significance. Some said that the NAM was nothing but a Cold War relic. Others said the NAM represented the interests of only some of its member countries. All NAM members had often been dragged along by the interests of a few member countries that were more outspoken and assertive. For this reason, in his farewell address in January 2001, the outgoing US Representative to the UN in New York, Richard Holbrooke, urged African countries to break away from the Movement. He said: "I respectfully ask the African countries here today to reconsider their association with the Non-Aligned Movement. The Non-Aligned Movement is not Africa's friend at this point. Your goals and NAM's are not synonymous." (Deen, 2001). As the NAM is entering the 21st century, it is facing new realities both inside and outside. While the NAM comprises the least developed and developing nations, many of its member countries are now emerging economies, such as India, Indonesia, Nigeria, Saudi Arabia and South Africa. Their influence on the global stage is increasing, both economically and politically. But will the Movement survive and be able to shape the future in yet another 60 years?

This article argues that the Movement will continue to be relevant for the near and far future of its member countries. It will continue to be meaningful to its member countries and the rest of the world if the NAM manages to set leadership diversification and achieve more visibility in providing solutions to global problems. It will remain significant if the Movement is able to enhance the commitment depth of its member countries, secure unity of voice and increase the level of multi-stakeholders internal support and participation. 


\section{The NAM: It all began in Belgrade}

The idea of non-aligned was translated into an institutionalised collaborative arrangement when leaders from twenty-five countries met at the first NAM Summit in Belgrade, Yugoslavia, on 1 - 6 September 1961. The Summit was convened amidst the Cold War that was intensely growing. The participating countries of the Summit mostly came from Asia and Africa, one from Latin America which was Cuba, and three observers which were Bolivia, Brazil, and Ecuador, and one from Europe which was the host of the Summit. Criteria for the NAM membership were successfully established in the Summit Preparatory Meeting in Cairo in June 1961 (Jansen, 1966, pp. 285-286; Gde Agung, 1973, p. 323). ${ }^{2}$ The founders of NAM viewed that the geopolitics of the time, the division of the Western Bloc led by the United States, and the Eastern Bloc controlled by the Soviet Union, has plunged the world into potential nuclear warfare. Therefore, the founders agreed that there had to be a forum for countries outside of those two blocs to unify efforts and resources to create a global order based on peace, equality, and justice. That forum was called the NAM. Issues of colonialism and neocolonialism became the NAM's agenda at the beginning of the Movement until the 6th NAM Summit in Havana, held in September 1979. This was understandable because at the time there continued to be colonial practices in several Asian and African countries, for example, Oman that was still colonised by the British, and the Portuguese colonies of Angola and Mozambique. The apartheid policy of the South African government also became one of the NAM's important agendas. The NAM gave attention to international economics as well as the development gap between developed and non-developing countries mainly caused by colonialism and imperialism. In order to create a more just global economy, the NAM has come up with several initiatives. At the 1961 Belgrade Summit, for example, the NAM suggested the United Nations to create the UN Capital Development Fund. Social issues such as education and culture garnered

\footnotetext{
${ }^{2}$ The criteria are: (i) a country should follow an independent policy based on peaceful co-existence and non-alignment, or should be showing a trend in favour of such a policy; (ii) it should consistently have supported movements for national independence; (iii) it should not be a member of multilateral military alliances concluded in the context of great power conflicts; (iv) if it had conceded military bases, these concessions should not have been made in the context of great power conflicts; (v) if it is a member of a bilateral or regional defence arrangement, this should not be in the context of great power conflicts.
} 
the NAM's attention at the Second Summit in Cairo, 5 - 10 October 1964. Leaders of the NAM realised the importance of culture, education, and science to increase development and strengthen freedom, justice, and peace. In this regard, the NAM underlined the importance of cooperation and exchanges of experience in those areas. The NAM also paid close attention to the issues of peace and international security. In addition to the Dasasila Bandung, the birth of the NAM was also influenced by the global tension created by the rivalry between the Western Bloc and the Eastern bloc. Facing this challenge, the NAM leaders tried to find a way out to deescalate tension and rivalry between these two blocs. Efforts to establish global peace continued to take place in the UN forum through what was named as "The Initiative of the Fives" which was spearheaded by the five NAM leaders which were the President of Ghana, Prime Minister of India, President of the Republic of Indonesia, President of Egypt, and President of Yugoslavia. The initiative was drafted into a resolution introduced by these five leaders to the President of the UN General Assembly on 30 September 1960 which demanded, among others, the UN members, specifically the United States and the Soviet Union, to decrease the tension between them to make way for peace and international security.

At the first Summit in Belgrade, the NAM leaders agreed to write a letter to President John F. Kennedy and Premier Nikita Khrushchev urging the two leaders to take steps to deescalate tension. Also, at the Summit, the members of NAM committed to preventing thermonuclear war. In relations to weapons disarmament, the NAM established the following three principles: (i) the NAM must be involved in any upcoming weapons disarmament conferences; (ii) all discussions related to weapons disarmament must be done within the UN framework; (iii) general and complete weapons disarmament must be guaranteed by an inspection and control involving the members of the NAM. Problems in the Middle East, including Palestine and Israel's aggression in Lebanon, became the attention of the NAM in the early 1970s. Since the 3rd Summit in Lusaka held from 8 - 10 September 1970, the issue of Palestine and the struggles of the Palestinian people became an important agenda for the NAM. Other issues of importance were racial discrimination, including the apartheid policy of South Africa. In this regard, the NAM has stated that by carrying out apartheid policy, the South African government is standing in opposition to UN resolutions on human rights and basic freedoms. During the Cold War in the 1970s, there was a surge of interdependence between countries. In this context, the NAM began to abandon the economic inequality argument that was based on colonialism. Instead, it began to place great 
importance on the finding of a new alternative global order that could be mutually beneficial for all countries. An alternative suggestion made by the NAM at the time was the New International Economic Order (NIEO). The NIEO concept received full support from the NAM leaders during the 4th Summit in Algeria on 5 - 9 September 1973. The Algerian Summit reiterated the NAM's commitment to this concept and urged for acceptance by the international community and to be implemented in stages. This effort successfully pushed for the adoption of the Declaration and Programme of Action for the Establishment of a New International Economic Order at the 6th UN General Assembly. The Declaration and Action of Programme showed a strong intention by the international community, specifically by the developing countries, to reject the old system based on exploitation and to create a new system based on equity, sovereign equality, interdependence, collective interest, and inter-nation cooperation. The adoption placed the NAM in the position of the initiator of new ideas, especially within the UN system. (Desai, 2008, p.193; Murthy, 2013, p. 134). Throughout the Cold War, the NAM became an entity that was reckoned with by the Western Bloc and the Eastern Bloc. The NAM became an alternative policy that was viable for several countries. The NAM's leverage in many issues during that time was quite big. The NAM's position towards problems in the Middle East and Palestine, apartheid and racial discrimination, weapons disarmament, and the NIEO became points of consideration by countries of the Western and Eastern blocs. In order to have effective activism in multilateral forums such as the UN, the NAM formed a Bureau of NAM Coordination and Caucus in the UN Security Council (UNSC). The Coordinating Bureau was given the mandate to coordinate activities with the NAM and to carry out duties assigned in the UN. Meanwhile, the NAM Caucus in the UNSC was formed to achieve an equal position with the UN members who sat in the Council. With the UNSC voting system that required affirmative votes from nine members (including votes from five permanent members), then the NAM through its Caucus has become an important factor in pushing forward or delaying issues relevant to the NAM priorities. In the post-Cold War era and the aftermath, the NAM was able to navigate through new challenges by commitments and recommitments to the Movement's principles and a variety of programmatic measures. Through a series of summitry diplomacy in Jakarta (1992), Cartagena de Indias (1995), Durban (1998), Kuala Lumpur (2003), Havana (2006), Sharm el-Sheikh (2009), Tehran (2012), Island of Margarita (2016) and Baku (2019), the Movement accentuated its determination to remain meaningfully existent and be part of the solution to global concerns. 


\section{Indonesia and the NAM}

The Non-Aligned Movement (NAM) is a premier forum for developing countries to collectively determine and fight for their various interests. For Indonesia, the NAM is one of the main pillars of its foreign policy which adopts the independent and active principle. Historically, the NAM has become an important mechanism for Indonesia in its efforts to achieve national interests and to establish a global order based on freedom, lasting peace, and social justice as mandated in the 1945 Constitution preamble. The independent and active foreign policy is also in line with the Bandung spirit and principles that provide the foundation of the NAM's presence and fight. The birth of the NAM was rooted in Dasasila Bandung (also known as the Ten Principles of Bandung) ${ }^{3}$ established by the 1955 Asia-Africa Conference. Dasasila Bandung encompasses the principles of international relations as envisioned by the Asian-African countries. Dasasila Bandung has not only inspired the acceleration of the decolonisation process and the emergence of new countries, but also the establishment of solidarity between developing countries, including the newly independent countries, within the context of international relations which was organised into competing blocs. The substance of "non-aligned" and the independent and active policy are quite closely related, even though they are different conceptually. As stated in the Explanation of Chapter 3 of Law No 37/1999, the definition of an independent and active foreign policy is "a foreign policy that is by nature not neutral, but a foreign policy that independently determines position and

\footnotetext{
${ }^{3}$ Dasasila Bandung (Ten Principles of Bandung): (i) respect for fundamental human rights and for the purposes and principles of the Charter of the United Nations; (ii) respect for sovereignty and territorial integrity of all nations; (iii) recognition of the equality of all races and of the equality of all nations, large and small; (iv) abstention from intervention or interference in the internal affairs of another country; (v) respect for the right of each nation to defend singly or collectively, in conformity with the Charter of the United Nations; (vi) (a) abstention from the use of arrangements of collective defence to serve the particular interests of any of the big powers, (b) abstention by any country from exerting pressures on other countries; (vii) refraining from acts or threats of aggression or the use of force against the territorial integrity or political independence of any country; (viii) settlement of all international disputes by peaceful means, such as negotiation, conciliation, arbitration or judicial settlement as well as other peaceful means of the parties own choice, in conformity with the Charter of the United Nations; (ix) promotion of mutual interests and co-operation; and (x) respect for justice and international obligations.
} 
policy towards international issues and does not commit a priori to one global power, and contributes actively through thoughts and active participation to resolve global conflicts, disagreements and other problems, in order to establish global order based on independence, lasting peace, and social justice." The NAM is also an instrument for multilateral cooperation based on the principles of equality, solidarity and togetherness, mutual respect, and mutual assistance. The NAM rejects unilateral steps taken either by one country or a group of its member or non-member countries. This is in line with Indonesia's foreign policy that emphasises multilateral diplomacy, together with bilateral diplomacy, to achieve common objectives and to contribute collectively to peace and international security efforts, as well as the welfare of countries in the world. Indonesia assumed its responsibility as the Chair of the NAM from 1992 to 1995. It was the period when a postCold World was steadily forming. It carried with it opportunities for less confrontational relations among countries and global euphoria for common peace and progress. Yet the Movement was cautiously optimistic, viewing the new world as remaining far from being peaceful, just and secure. As reflected in the document of the 1992 Jakarta Message, the NAM leaders believed that the world today is still far from being a peaceful, just and secure place. Simmering disputes, violent conflicts, aggression and foreign occupation, interference in the internal affairs of states, policies of hegemony and domination, ethnic strife, religious intolerance, new forms of racism, and narrowly conceived nationalism are major and dangerous obstacles to harmonious co-existence among states and peoples and have even led to the disintegration of states and societies (Ministry of Foreign Affairs of the Republic of Indonesia, 1992, para. 3). Indonesia's NAM chairmanship that coincided with the end of the Cold War era was called upon to respond to the new development, and to the urgency to define the NAM's role and position within the new international order. For Indonesia, the NAM's ability to respond and adapt to the new challenges was essential for the NAM to remain relevant for its members and beyond. To begin, Indonesia in its capacity as the NAM's chair placed great significance on securing the collective commitment of the NAM member states to making the Movement pertinent. In the 1992 Summit, as reflected in its document, leaders of the Movement agreed (...), the Movement is committed to the shaping of a new international order, free from war, poverty, intolerance and injustice, a world based on the principles of peaceful co-existence and genuine interdependence, a world which takes into account the diversity of social systems and cultures ((Ministry of Foreign Affairs of the Republic of Indonesia, 1992, para. 27). The commitment was to be substantiated. And 
Indonesia was well aware of this. The chair's first test was a conflict in Bosnia and Herzegovina that posed serious threats to international peace and security. The conflict preoccupied the NAM's agenda, and the Summit tasked Indonesia to "closely monitor the situation and to take appropriate action to give support to peace initiatives of the United Nations." (Ministry of Foreign Affairs of the Republic of Indonesia, 1992, para. 40). In accordance with the mandate, Indonesia took a range of initiatives, including appointing a Special Envoy tasked to liaise with leaders of key countries, including the United Kingdom, Germany, the Russian Federation and Turkey. This step was compounded by a mission led by President Soeharto to Zagreb and Sarajevo on 12 - 14 March 1995. At the same time, Indonesia extended to Croatia, Bosnia and Herzegovina, Serbia, Macedonia and Slovenia an offer of good offices, on behalf of the Movement, to facilitate the peace process in the Balkan region (Ministry of Foreign Affairs of the Republic of Indonesia, 1995, pp. 4-5). The conflict in the Balkans was not the only threat to international peace and security that created pressure on the international community. The NAM also had to respond to the unfolding inter-ethnic conflict in Rwanda. In a meeting in October 1994, the NAM's Foreign Ministers urged the cessation of violence that could spiral up to genocide. The Foreign Ministers also welcomed the intention of the United Nations to establish an international tribunal to bring perpetrators to justice. One year later, in a Coordinating Bureau Meeting of the NAM in Bandung in April 1995, the NAM's Foreign Ministers called for the urgency of post-conflict reconstruction and rehabilitation.

The end of the Cold War also carried with it a strong hope of the NAM member countries for an increase in North-South dialogue and South-South cooperation. In July 1993 Japan in its capacity as the Chair of G7 invited Indonesia for a discussion on measures to be taken to strengthen the NorthSouth dialogue. To create a global cushion for such a dialogue, the NAM spearheaded multilateral discussions on the North-South dialogue and ways to strengthen it. The discussions led to the adoption of the UN General Assembly resolution 48/165 "Renewal of the Dialogue on Strengthening International Economic Cooperation for Development through Partnership." One issue that was high on the agenda of the NAM that was critical to the dialogue was foreign debt. Indonesia regarded this issue as one of its NAM priorities and viewed that foreign debt resolution should be effective, comprehensive, fair, development-oriented, and durable. In August 1994 Indonesia hosted a Ministerial Meeting that focused on foreign debt and development. The Ministers outlined and gave emphasis to the "once and for all" principle in debt resolution and called for a substantial 
reduction of up to 70 per cent for all categories of foreign debt. In the framework of South-South cooperation, Indonesia proposed a tripartite financing mechanism. In December 1994, at the United Nations, the NAM in collaboration with Group 77 pioneered the adoption of the UN resolution on "The United Nations Conference on South-South Cooperation".

\section{The NAM's Relevance}

The question of the NAM's relevance was particularly arising when the Cold War era ended. In the first ten years of transition from the Cold War to the post-Cold War era, the NAM was facing a number of challenges that posed a test to the Movement's relevance. One of the challenges was an increase in intra-state conflicts as found among others in Liberia, the Democratic Republic of the Congo, Rwanda, Sierra Leone and the Balkan region. With the event of 9/11 unfolding, the NAM member countries had to adjust to the new global reality that gave birth to a new bipolar world established under the dictum "you are either with us, or with the terrorists." In the same period, the NAM had to respond to the globally growing demand for democracy and the promotion and protection of human rights, the desire for social progress, poverty alleviation and economic progress, the reduction or exemption of foreign debts, and the need for a fair international trading system and financing for sustainable development. There was a sentiment that cast doubt on the efficacy of the NAM in helping its member countries achieving these goals. In 2005, for example, the US Congress as stated in the report American Interests and UN Reform: Report of the Task Force on the United Nations takes the view that "the so-called NonAligned Movement, a product of Cold War divisions, remains as a major impediment to economic development, protection of human rights and the promotion of democracy." (USIP, 2005, p.6). The US Congress viewed that the NAM was just an obstacle to making progress in critical areas of human development. Today, the global politics landscape is immensely transforming. China is steadily emerging as a major power and its rise and relations with the US and the rest of the globe is shaping international relations of our time. The world is also facing disruptive waves, including industrial revolution 4.0 and Covid-19. The NAM has to find its place as a forum for collectively effective measures in responding to the disruptions, to show its meaningful existence for its member countries and the rest of the global community of nations. In other words, the NAM has to prove that it remains relevant to its member states and the milieu and other states outside the Movement. This article argues that the NAM's relevance would 
continue and significantly be felt by its member countries, especially within the present context of multi-dimensional developments and disruptions, if the Movement meets or continues to meet the following strategies:

First, is leadership diversification. The NAM diversifies its leadership. Since 1961, the NAM's chair has been decided on a geographically rotating basis. So far, five countries in Asia have assumed the chairmanship position: Sri Lanka (1976), India (1983), Indonesia (1992), Malaysia (2003), Iran (2012) and Azerbaijan (2019); five countries from Africa: Egypt (1964 \& 2009), Zambia (1970), Algeria (1973), Zimbabwe (1986) and South Africa (1998); one from Europe: Yugoslavia (1961 \& 1989); and three from Latin America: Cuba (1979 \& 2006), Colombia (1995) and Venezuela (2016). With 120 member countries, the NAM's chairmanship and leadership need to go beyond this pattern. The NAM may wish to anticipate the fact that in the future, Chile, Nigeria, Singapore, Thailand, the Philippines or Vietnam or else should chair and lead the Movement if they wish to do so. Diversity in leadership will enrich the NAM with traditions in governance. Second, greater visibility in solving global problems is another important element of the NAM's constant relevance. Critical to this visibility is leaders' innovation in finding solutions. The chair of the Movement may wish to use good offices or advisory offices, leader's missions, leader's special envoys, leader's Sherpa, ad-hoc task forces, confidence-building missions, or contact groups in helping resolve global and regional conflicts and disputes. The present situations in Syria, Yemen, and, of course, the protracted Israeli-Palestinian conflict seem to call for such initiatives. The decision of the NAM under the chairmanship of Azerbaijan, during the Online Summit Level Meeting of the NAM Contact Group in Response to Covid-19 on 4 May 2020, to establish a NAM Task Force in the fight against Covid-19 was very timely. Third, it is important for the NAM to make more deliverables in the future, both in dispute settlements among its members and meeting the socio-economic and development needs of its members. Conflicts and disputes still take place within and between some NAM member countries. Covid-19, climate change and poverty alleviation remain high on the agenda of the Movement. Fourth, the NAM needs to go beyond conference room deliberations in catering to the fundamental needs of the peoples of its members. It needs to go beyond the lengthy and thick final documents that are traditionally adopted at the end of a NAM Summit or ministerial meeting. The NAM member countries need to have commitment depth, which is the level of their commitment to the implementation of the principles and programmatic goals outlined in the outcome documents of collaborative arrangements. Commitment depth reflects the level of priority and significance that the NAM member countries 
place on the Movement. Fifth, the NAM will need greater unity of voice in responding to future challenges. The unity of voice also reflects strong leadership and strong cohesion of the movement. When the NAM member states speak with one voice, it will have a better chance to achieve a symmetrical result in its diplomacy. Sixth, in the present and future world where the government is no longer the only actor that decides the fate of the NAM, the cause of the Movement will be strengthened when it enjoys unflagging support, let alone active participation, from its peoples. Therefore, the NAM might also wish to explore the greater contribution of the business sector and civil society groups from each of its member countries for the enhancement of the NAM cooperation.

\section{Conclusions}

Since its inception in Belgrade in 1961, the NAM has become a critical entity that shapes relations among nations in the Cold War as well as postCold War era and beyond. The NAM grouping has been an essential negotiation bloc, especially within the United Nations forums, which provided alternative perspectives and positions amidst contention between the Western and the Eastern bloc. In the present time, while its member countries continue to place great importance on the NAM, the question of its relevance and significance ceaselessly overshadows the Movement. The NAM has always been a critical part of Indonesia's active and independent foreign policy. When it chaired the Movement in 1992 - 1995, Indonesia succeeded at ensuring seamless NAM's transition, leaving the Cold War to enter the new context of post-Cold War international relations. It managed to give meaning to the continued relevance of the Movement, including through programmatic activities that responded to the pressing concerns of the Movement's member countries.

\section{References}

Cavoški, J. (2015). Distant Countries, Closest Allies: Josip Broz Tito and Jawaharlal Nehru and the rise of global non-alignment. Nehru Memorial Museum and Library.

Deen, Thalif (2001, February 19). Politics: Non-Aligned Movement hits back at outgoing US Envoy. Inter Press Service News Agency, retrieved from http://www.ipsnews.net/2001/02/ politics-non-aligned-movementhits-back-at-outgoing-us-envoy/. Accessed 25 March 2021. 
Dinkel, Jürgen. (2018). The Non-Aligned Movement: Genesis, Organization and Politics (1927-1992). Leiden, The Netherlands: Brill.

Gde Agung, Ide Anak Agung. (1973). Twenty years Indonesian foreign policy. The Hague, Mouton \& Co.

Hennie Strydom. (Eds.). (2007). The Non-Aligned Movement and the Reform of International Relations. Max Planck Yearbook of United Nations Law, Volume 11, 1-46. Leiden, The Netherlands: Brill | Nijhoff.

Jansen, G.H. (1966). Nonalignment and the Afro-Asian States. New York, Praeger.

Keethaponcalan, S.I. (2016). Reshaping the Non-Aligned Movement: challenges and vision. Bandung Journals of Global South, 3(01), 1-14.

Mbaidjol, N. K. (2018). “The Shift Toward 'Multipolarity': Multipolarity and the Non-Aligned Movement (NAM)". In African Countries and the Global Scramble for China. Leiden, The Netherlands: Brill.

Ministry of Foreign Affairs of the Republic of Indonesia. (1992). The Jakarta Message: A Call for Collective Action and the Democratization of International Relations, Final Document of the $10^{\text {th }}$ NAM Summit (NAC 10/Doc. 1/Rev. 2), Jakarta.

Ministry of Foreign Affairs of the Republic of Indonesia. (1995). Report of the Chairman of the Non Aligned Movement on the Activities of the Movement (September 1992 - October 1995), Jakarta.

Miskovic, N., Fischer-Tiné, H., \& Boskovska, N. (Eds.). (2014). The NonAligned Movement and the Cold War: Delhi - Bandung - Belgrade (1st ed.). Routledge.

Murthy, C.S.R. (2013). Non-Aligned Movement countries as drivers of change in international organizations. Comparativ, 23(4/5), 118-136.

Stojanovic, R. (1981). The Emergence of the Non-Aligned Movement: A View from Belgrade. Case W. Res. J. International Law, 13(3), 443-450.

Sutresna, Nana. (1995). Berbagai Upaya Memperjuangkan Kepentingan GNB di PBB. Jakarta, BPK GNB Departemen Luar Negeri RI.

United States Institute of Peace. (2005). American Interests and UN Reform: Report of the Task Force on the United Nations, Washington, DC.

Vieira, Marco A. (2016). Understanding Resilience in International Relations: The Non-Aligned Movement and Ontological Security. International Studies Review, vol. 18(2), 290-311. 